University of Nebraska - Lincoln

DigitalCommons@University of Nebraska - Lincoln

USDA National Wildlife Research Center - Staff Publications
U.S. Department of Agriculture: Animal and Plant Health Inspection Service

2010

\title{
Promiscuous mating in feral pigs (Sus scrofa) from Texas, USA
}

Johanna Delgado-Acevedo

Texas A\&M University-Kingsville

Angeline Zamorano

Texas A\&M University-Kingsville

Randy W. DeYoung

Texas A\&M University-Kingsville, randall.deyoung@tamuk.edu

Tyler A. Campbell

United States Department of Agriculture, tcampbell@eastfoundation.net

David G. Hewitt

Texas A\&M University-Kingsville, david.hewitt@tamuk.edu

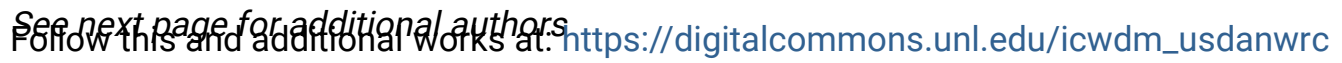

Part of the Natural Resources and Conservation Commons, Natural Resources Management and Policy Commons, Other Environmental Sciences Commons, Other Veterinary Medicine Commons, Population Biology Commons, Terrestrial and Aquatic Ecology Commons, Veterinary Infectious Diseases Commons, Veterinary Microbiology and Immunobiology Commons, Veterinary Preventive Medicine, Epidemiology, and Public Health Commons, and the Zoology Commons

Delgado-Acevedo, Johanna; Zamorano, Angeline; DeYoung, Randy W.; Campbell, Tyler A.; Hewitt, David G.; and Long, David B., "Promiscuous mating in feral pigs (Sus scrofa) from Texas, USA" (2010). USDA National Wildlife Research Center - Staff Publications. 1261.

https://digitalcommons.unl.edu/icwdm_usdanwrc/1261

This Article is brought to you for free and open access by the U.S. Department of Agriculture: Animal and Plant Health Inspection Service at DigitalCommons@University of Nebraska - Lincoln. It has been accepted for inclusion in USDA National Wildlife Research Center - Staff Publications by an authorized administrator of DigitalCommons@University of Nebraska - Lincoln. 


\section{Authors}

Johanna Delgado-Acevedo, Angeline Zamorano, Randy W. DeYoung, Tyler A. Campbell, David G. Hewitt, and David B. Long 


\title{
Promiscuous mating in feral pigs (Sus scrofa) from Texas, USA
}

\author{
Johanna Delgado-Acevedo ${ }^{\mathrm{A}}$, Angeline Zamorano ${ }^{\mathrm{A}}$, Randy W. DeYoung ${ }^{\mathrm{A}, \mathrm{C}}$, \\ Tyler A. Campbell ${ }^{\mathrm{B}}$, David G. Hewitt ${ }^{\mathrm{A}}$ and David B. Long ${ }^{\mathrm{B}}$

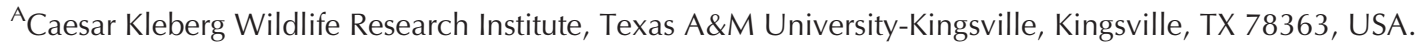 \\ ${ }^{B}$ United States Department of Agriculture, Animal and Plant Health Inspection Service, Wildlife Services, \\ National Wildlife Research Center, Texas A\&M University-Kingsville, Kingsville, TX 78363, USA. \\ ${ }^{\mathrm{C}}$ Corresponding author. Email: randall.deyoung@tamuk.edu
}

\begin{abstract}
Context. Feral pigs represent a significant threat to agriculture and ecosystems and are disease reservoirs for pathogens affecting humans, livestock and other wildlife. Information on the behavioural ecology of feral pigs might increase the efficiency and effectiveness of management strategies.

Aims. We assessed the frequency of promiscuous mating in relation to oestrous synchrony in feral pigs from southern Texas, USA, an agroecosystem with a widespread and well established population of feral pigs. An association between multiple paternity of single litters and synchrony of oestrous may indicate alternative mating strategies, such as mateguarding.

Methods. We collected gravid sows at nine sites in southern Texas during 2005-07. We used a panel of DNA microsatellite markers to estimate frequency of multiple paternity and the distribution of male mating among litters of feral pigs. Conception dates were determined by fitting average fetal crown-rump measurements within litters to expected fetal development relative to gestation time.

Key results. We found evidence of multiple paternity in 21 of 64 litters (33\%) from seven of nine sites sampled. Synchrony of oestrous did not influence promiscuous mating, as we found multiple paternity at sites with synchronous and asynchronous oestrous. Males sired from 8 to 11 offspring at three sites where $>10$ litters were sampled. Mean litter size (5.4) was less than the best-fit value for the number of offspring, indicating that some males sired offspring with $\geq 2$ females.

Key conclusions. Feral pigs in Texas appear to be promiscuous under a range of demographic conditions, unlike wild boar and feral pigs in other regions. The ecological and behavioural factors affecting multiple paternity are not clear, but may include male-male competition, harassment avoidance, genetic benefits for offspring, response to macro-habitat conditions, or selection.

Implications. A high incidence of sexual contact among individuals may increase the opportunity for diseases transmitted by oral or venereal routes, such as swine brucellosis and pseudorabies. In addition, fertility-control methods targeting males only are likely to be inefficient if female promiscuity is high; methods targeting females or both sexes jointly may be more effective.
\end{abstract}

\section{Introduction}

Feral pigs (Sus scrofa) are currently the most abundant exotic wild ungulate in the United States and are a significant pest in many countries worldwide (Bieber and Ruf 2005). Feral pigs are the descendants of escaped domestic swine, Eurasian wild boar, and their hybrids (Sweeney et al. 2003). Feral populations have been present in the United States for more than four centuries; however, the number and distribution of feral pigs has increased dramatically in recent decades. Population surveys conducted in the United States during 1981 and 1988 indicated that feral pigs occurred in 18 south-eastern states and California (Mayer and Brisbin 1991). By 1990, feral pigs were present in at least 23 states (Miller 1993; Taylor 1993; Stevens 1996; Gipson et al. 1998). The most recent survey reports feral pigs occurring in 28 states, spanning the United States from California to Virginia, with isolated populations further north (Southeastern Cooperative Wildlife Disease Study 2009). Recent estimates of the total population in the United States are up to 4 million individuals (Nettles 1997; Pimentel et al. 2005), with as many as 2 million occurring in Texas (Mapston 2004).

Feral pigs compete for resources with native wildlife (Gipson et al. 1998), and predate on domestic livestock and ungulate game species (Dickson et al. 2001). Feral pigs represent a significant threat to natural ecosystems (Adams et al. 2005), and are disease reservoirs for a variety of zoonotic pathogens (Dickson et al. 2001; Sweeney et al. 2003). As feral-pig populations continue to expand, their management may become increasingly critical for the conservation of ecosystems, economies and the health of wildlife, livestock and humans (Pimentel et al. 2005). Eradication of feral pigs from most of the United States is unlikely because of their broad geographic distribution and high reproductive potential (Taylor et al. 1998). Current management involves a combination of lethal and non-lethal methods (e.g. fencing or exclusion) to 
temporarily control feral pigs, thus alleviating seasonal damage (Kammermeyer et al. 2003). Clearly, there is a need for improving efficiency and effectiveness of management.

The behaviour and life-history traits of invasive species often contribute to the competitive ability of invasives when introduced into novel environments. Thus, management programs that incorporate ecological characteristics of the invasive species may be more efficient and cost-effective. To this end, Witmer et al. (2003) proposed empirical and model-based studies of fertility control and feral-pig ecology and behaviour as related to disease transmission as priorities for research and management of feral pigs in the United States. Aspects of feral-pig mating behaviour have clear implications for disease transmission and assessing the efficacy of population-control methods. There have been few studies of feral-pig mating behaviour because of the pigs' secretive nature and preference for dense habitats (Taylor et al. 1998; Hampton et al. 2004a).

Studies based on visual observation suggest that feral pigs may be promiscuous (Barrett 1978), and the reproductive anatomy of male feral pigs (large testicles relative to body size) suggests adaptation to sperm competition and multiple mating (Kenagy and Trombulak 1986). Recently, the availability of variable genetic markers (Fleischer 1996) and improved analysis methods (e.g. Marshall et al. 1998; Jones and Ardren 2003; De Woody 2005) has enabled increasingly detailed studies of parentage and relationships among individuals. However, studies of genetic parentage in wild pigs have produced conflicting results, suggesting that feral-pig mating behaviour may vary among populations because of habitat, demography or other factors (Hampton et al. 2004a; Delgado et al. 2008).
The objective of the present study was to provide information on the mating behaviour of feral pigs in southern Texas, a semiarid region containing a high density of feral pigs where landowners and producers experience significant annual loss because of feralpig damage. Specific objectives were to (1) quantify the frequency of multiple paternity (siring of litters by $>1$ male) in feral pigs, (2) quantify the putative number of offspring sired per male and (3) assess synchrony of oestrous in feral pigs. This information will reveal the extent of promiscuity as well as the ability of males to monopolise oestrous females.

\section{Materials and methods}

\section{Sample collection}

We sampled feral pigs at sites representing seven counties in southern Texas (Cameron, McMullen, Dimmit, Brooks, Hidalgo, San Patricio and Kleberg), and two counties in central Texas (Kerr and Coryell) during 2005-07 (Fig. 1). Feral pigs were trapped, harvested or removed by aerial and ground shooting as part of damage-control management activities and sport hunting. Most samples within counties were collected at one or a few geographically proximate sites. We designated samples by county to preserve the anonymity of private land stewards who allowed access for trapping and harvesting. Previous research in southern Texas indicated seasonal peaks in reproduction, where pregnant sows were found during January-March and June-July (Taylor et al. 1998). We sampled as opportunities arose, but attempted to focus collections during these months whenever possible, to increase our chances of detecting litters with visible fetuses. We collected muscle-tissue biopsies from all individuals;

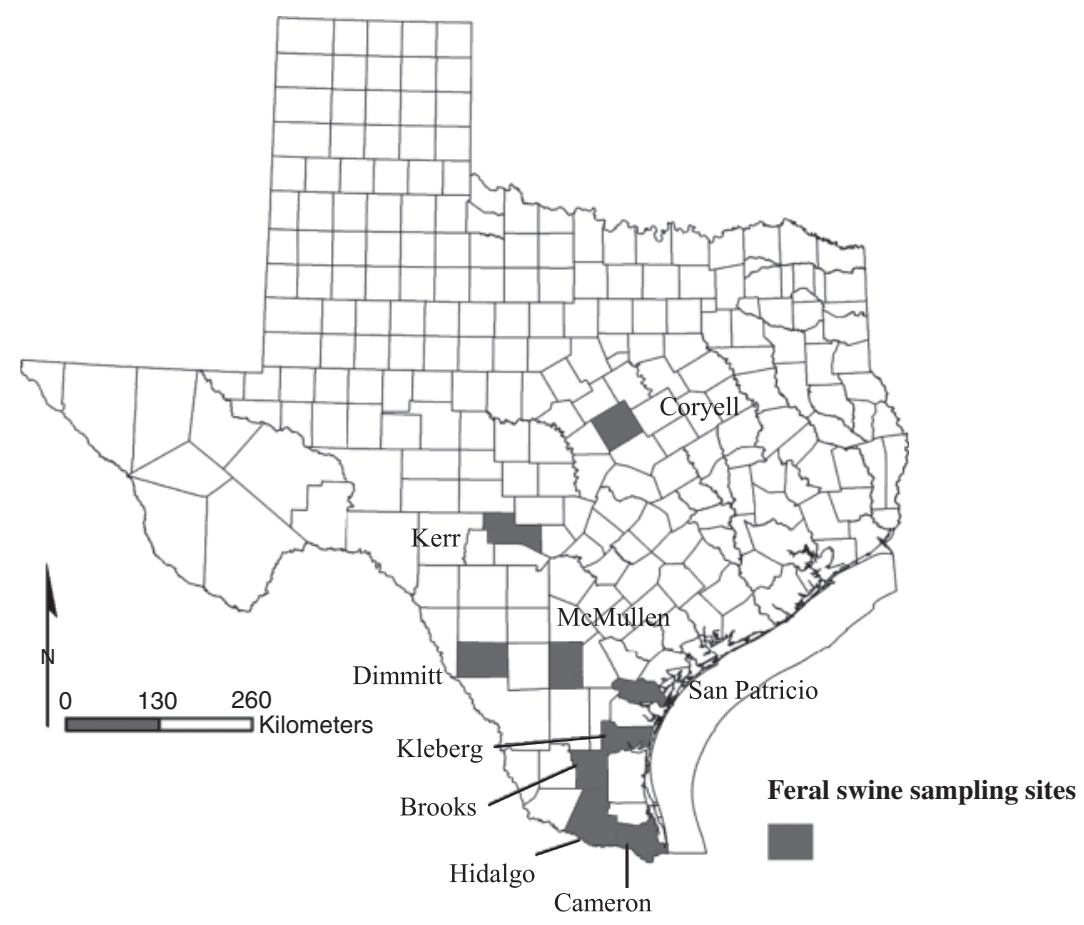

Fig. 1. Sample collection locations for feral pigs in southern Texas, collected during 2005-07. We confirmed multiple paternity in seven of the nine counties on the basis of data from 12 microsatellite DNA markers. 
we necropsied all females and removed embryos if present. We placed biopsies in individual sterile plastic bags and stored them at $-20^{\circ} \mathrm{C}$.

\section{DNA extraction and amplification}

We extracted DNA from the tissue samples with a commercial kit (Qiagen DNeasy, Qiagen Genomics, Bothell, Washington, USA). We used 12 fluorescent-tagged polymorphic DNA microsatellite markers from Set XI (the diversity panel), developed by the United States Pig Genome Coordination Program (http://www.animalgenome.org/pigs/, accessed 21 June 2005), to genotype the samples, following Hampton et al. (2004b). The diversity-panel loci amplify well, with no indication of null alleles and the chromosome positions are known, facilitating an index of genome-wide genetic diversity without physical linkage. We loaded samples into an ABI 3130 automated DNA sequencer (Applied Biosystems, Foster City, California, USA) for separation and detection. We binned and assigned alleles and constructed multilocus genotypes by using the computer software GeneMapper (Applied Biosystems). We used a strict allele-calling protocol, where an individual was re-typed for a locus if alleles amplified weakly; we made no size-calls if an allele peak appeared with a fluorescencesignal intensity $<100$ as estimated by GeneMapper. We also re-typed $30 \%$ of individuals to assess the accuracy of typing.

\section{Data analysis}

Microsatellite alleles are inherited in Mendelian fashion (e.g. one from each parent). Thus, if the maternal genotype is known, one can identify paternal alleles in a litter of more than two offspring. Any litter with more than two paternal alleles at a locus is a candidate for multiple paternity (Fig. 2). We defined multiplysired litters according to the following criteria: (1) all fetal genotypes contained at least one maternal allele that was consistent within the litter; (2) the paternal alleles could not be accounted for by one sire because of violation of Mendelian inheritance; and (3) the litter had more than two paternal alleles at two or more loci.

Our sampling precluded many standard paternity analyses (e.g. Marshall et al. 1998; De Woody 2005) because the sample of potential sires was incomplete and it is difficult to estimate critical parameters needed for parentage simulations, such as the number of sires and the proportion of putative parents sampled. However, the inclusion of known dams allowed us to identify and analyse the paternal alleles. This approach allows inferences about the distribution of male reproductive success without requiring sampling all of the males. We used a Monte Carlo randomisation algorithm (DadShare, Hoffman et al. 2003; available from www.zoo.cam.ac.uk/zoostaff/amos, accessed 14 October 2009), to estimate the average sibship size that best explained the empirical data. The algorithm first identifies paternal alleles for each offspring in each litter, then calculates a matrix of pairwise paternal relatedness between the offspring samples on the basis of Queller and Goodnight's (1989) relatedness estimator. The matrix is then reduced to a dendrogram by using the unweighted pair-group method with arithmetic averages (UPGMA; Sneath and Sokal 1973) algorithm, assuming that close relatives will cluster at the nodes of the dendrogram. Finally, the algorithm simulates

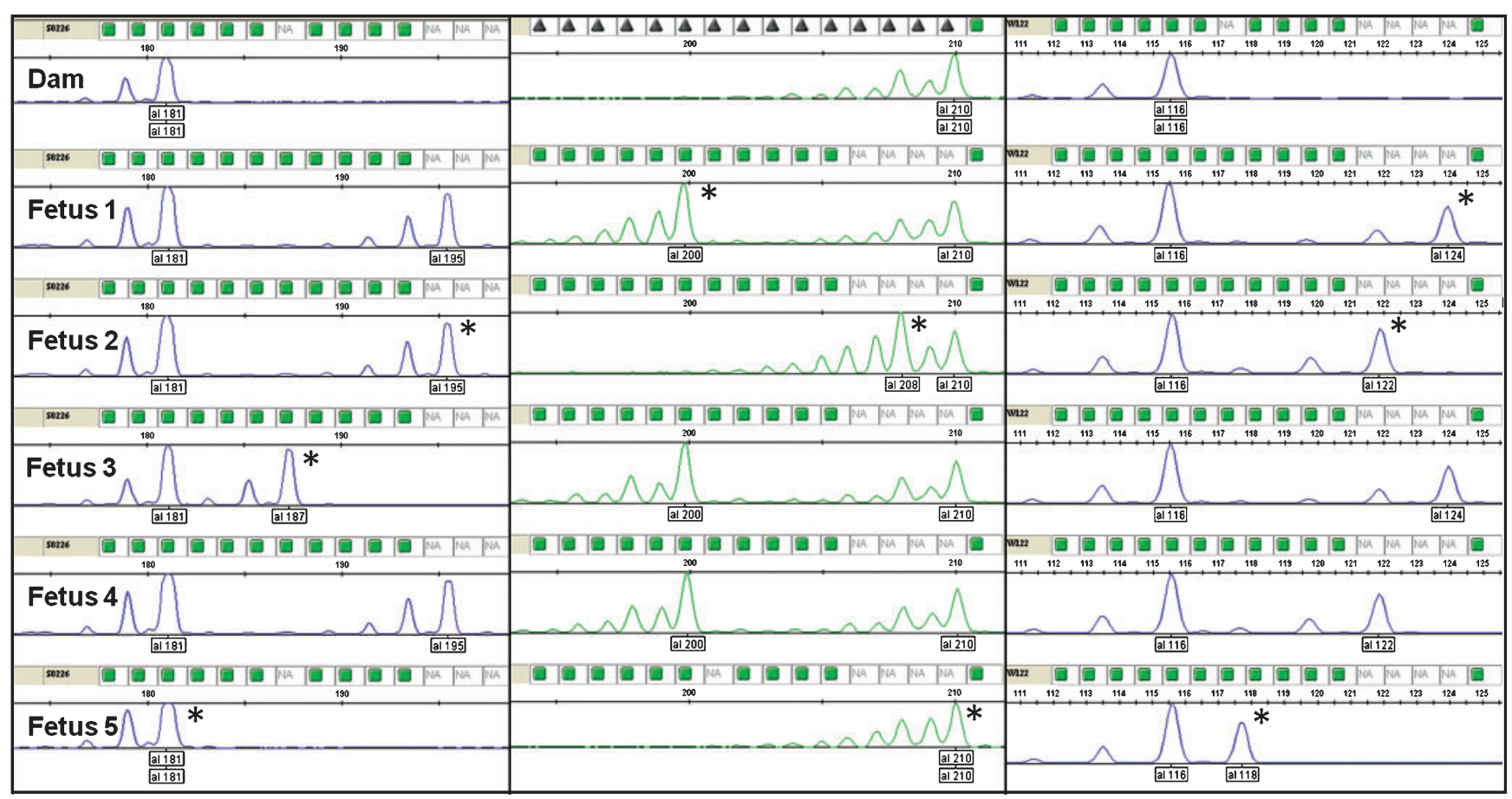

Fig. 2. Sample electropherograms for 3 of the 12 DNA microsatellite loci amplified in litters of feral pigs. For litters sampled in utero, the dam's genotype is known and paternal alleles can be identified. The presence of three or more paternal alleles at multiple loci within a single litter provides clear empirical evidence for multiple paternity. Paternal alleles are designated with an asterisk. 
expected results over a range of sires and a range of offspring produced by each sire, by using Monte Carlo randomisations and the empirical estimates of allele frequencies. Specifically, for $n$ offspring, the program conducts 10 different simulation scenarios, one each for $1-5, n / 5, n / 4, n / 3, n / 2$, and $n$ sires, where each sire produces $n, n / 2, n / 3, n / 4, n / 5$, and $1-5$ offspring. Each of the 10 scenarios is repeated 10 times and the mean and s.d. of relatedness values are output for comparison to the empirical data. We used the DadShare algorithm to analyse sibship data from collection sites in Kleberg, San Patricio, and McMullen counties, where the sample size of litters was sufficient for inference. We used empirical values based on all adults collected at each site to ensure a reasonable estimate of allele frequencies for the DadShare analysis.

We assessed oestrous synchrony at each sampling site where multiple sows were collected. We measured crown-rump length of fetuses (Mayer and Brisbin 1991) and estimated fetal ages (days since conception) after Odlaug (1965), assuming a 115-day gestation. We used only samples taken during a discrete season or calendar year at a site to assess synchrony. The range of conception dates at each site provides an index of oestrous synchrony, which may affect the ability of dominant males to monopolise access to oestrous females.

\section{Results}

We collected 64 pregnant sows and 345 fetuses. Mean litter size was 5.4 (range $=2-11$ ). The microsatellite markers were polymorphic in Texas feral pigs. We observed 100 total alleles; mean number of alleles per locus was 8.3, and an expected heterozygosity $\left(H_{\mathrm{e}}\right) \quad 0.70$ (Table 1$)$. We found evidence of multiple paternity in 21 of 64 litters $(33 \%)$ and at seven of nine sites; the other two sites had two or fewer litters (Table 2). Mean litter size for litters with more than one sire and for single-sire litters was 5.8 and 4.4, respectively. The number of litters sampled limited our ability to generate site-specific estimates of multiple paternity. Two sites with a reasonable sample size displayed similar rates of multiple paternity; McMullen $(n=16)$ and San Patricio $(n=18)$ counties had $38 \%$ and $39 \%$ occurrence, respectively (Table 1$)$.

Table 1. Observed $\left(H_{0}\right)$ and expected heterozygosity $\left(H_{\mathrm{e}}\right)$, number of alleles $(K)$, and number of individuals $(N)$ for 12 microsatellite DNA loci amplified in feral-pig populations from Texas, USA, collected during 2005-07

\begin{tabular}{lrccc}
\hline Locus & $K$ & $N$ & $H_{\mathrm{o}}$ & $H_{\mathrm{e}}$ \\
\hline S0002 & 9 & 324 & 0.599 & 0.739 \\
S0026 & 4 & 396 & 0.558 & 0.620 \\
S0068 & 12 & 329 & 0.660 & 0.775 \\
S0090 & 5 & 349 & 0.458 & 0.526 \\
S0155 & 8 & 360 & 0.675 & 0.756 \\
S0226 & 7 & 389 & 0.692 & 0.750 \\
SW122 & 8 & 396 & 0.758 & 0.807 \\
SW240 & 11 & 333 & 0.703 & 0.833 \\
SW857 & 4 & 262 & 0.294 & 0.547 \\
SW911 & 6 & 393 & 0.565 & 0.575 \\
SW936 & 9 & 377 & 0.780 & 0.838 \\
SW951 & 6 & 391 & 0.394 & 0.390 \\
\hline
\end{tabular}

The analysis of paternal alleles confirmed the multiplepaternity results. We estimated that males in Kleberg County sired about eight fetuses in the sampled population, and 11 and 7 in San Patricio and McMullen County populations, respectively (Fig. 3). Mean litter sizes were 6.5, 5.1 and 5.5 in Kleberg, San Patricio and McMullen, respectively; all were less than the best-fit value for the number of offspring per sire. Therefore, the simulation results indicated that some males sired offspring with at least two females (Fig. 3).

The in utero sex ratio $(\mathrm{M}: \mathrm{F})$ was $159: 186$ for all litters. Fetuses ranged from 9.2 to $22.1 \mathrm{~cm}$ in length. We obtained fetallength measurements at four sites, enabling an assessment of oestrous synchrony. Sows collected at two sites displayed nonconcurrent oestrous, with litters conceived over a period of 55 and 79 days, respectively, in McMullen and Kleberg counties. In contrast, sows collected in San Patricio displayed a bimodal pattern, with oestrous cycles twice a year (spanning 11 days for the first mode and 7 days for the second). Sows in Dimmit County had a relatively synchronous oestrous, spanning 25 days.

\section{Discussion}

Multiple paternity appears common and widespread among feral pigs in southern Texas, and occurred in about one-third of litters sampled (Table 2). As not all matings result in conception, our estimates of the rate of multiple mating are likely conservative. Our findings confirm previous anecdotal observations of several feral-pig males breeding with the same female during one oestrus cycle (Barrett 1978), resulting in multiple-sired litters in some populations of feral pigs. The high number of litters sired by more than one male and the number of sire contributions to each litter confirm a highly promiscuous system in feral pigs. In contrast, recent genetic-based studies found low rates of multiple mating in European wild boar, which the authors attributed to mateguarding behaviour (Delgado et al. 2008) and to the removal of individuals during hunting (Poteaux et al. 2009). Hampton et al. (2004a) found no evidence of multiple mating in south-western

Table 2. Number of litters and the rate of multiple paternity in feral-pig populations sampled in nine counties of central and southern Texas, USA, during 2005-07

Non-pregnant sows include juveniles and sows that may have been bred, but did not have visible fetuses

\begin{tabular}{lcccc}
\hline County & $\begin{array}{c}\text { Non-pregnant } \\
\text { sows }\end{array}$ & $\begin{array}{c}\text { Total (males } \\
\text { and females) }\end{array}$ & $\begin{array}{c}\text { Sows } \\
\text { with litters }\end{array}$ & $\begin{array}{c}\text { Litters } \\
\text { with multiple } \\
\text { paternity (\%) }\end{array}$ \\
\hline Brooks & 35 & 69 & 2 & 1 \\
Cameron & 31 & 65 & 5 & 2 \\
Coryell & 8 & 22 & 2 & 0 \\
Dimmit & 12 & 56 & 8 & 1 \\
Hidalgo & 3 & 10 & 1 & 0 \\
Kerr & 0 & 1 & 1 & 1 \\
Kleberg & 56 & 177 & 11 & $3(27)$ \\
McMullen & 55 & 124 & 16 & $6(38)$ \\
San Patricio & 46 & 130 & 18 & $7(39)$ \\
Total & 246 & 654 & 64 & $21(33)$ \\
\hline
\end{tabular}



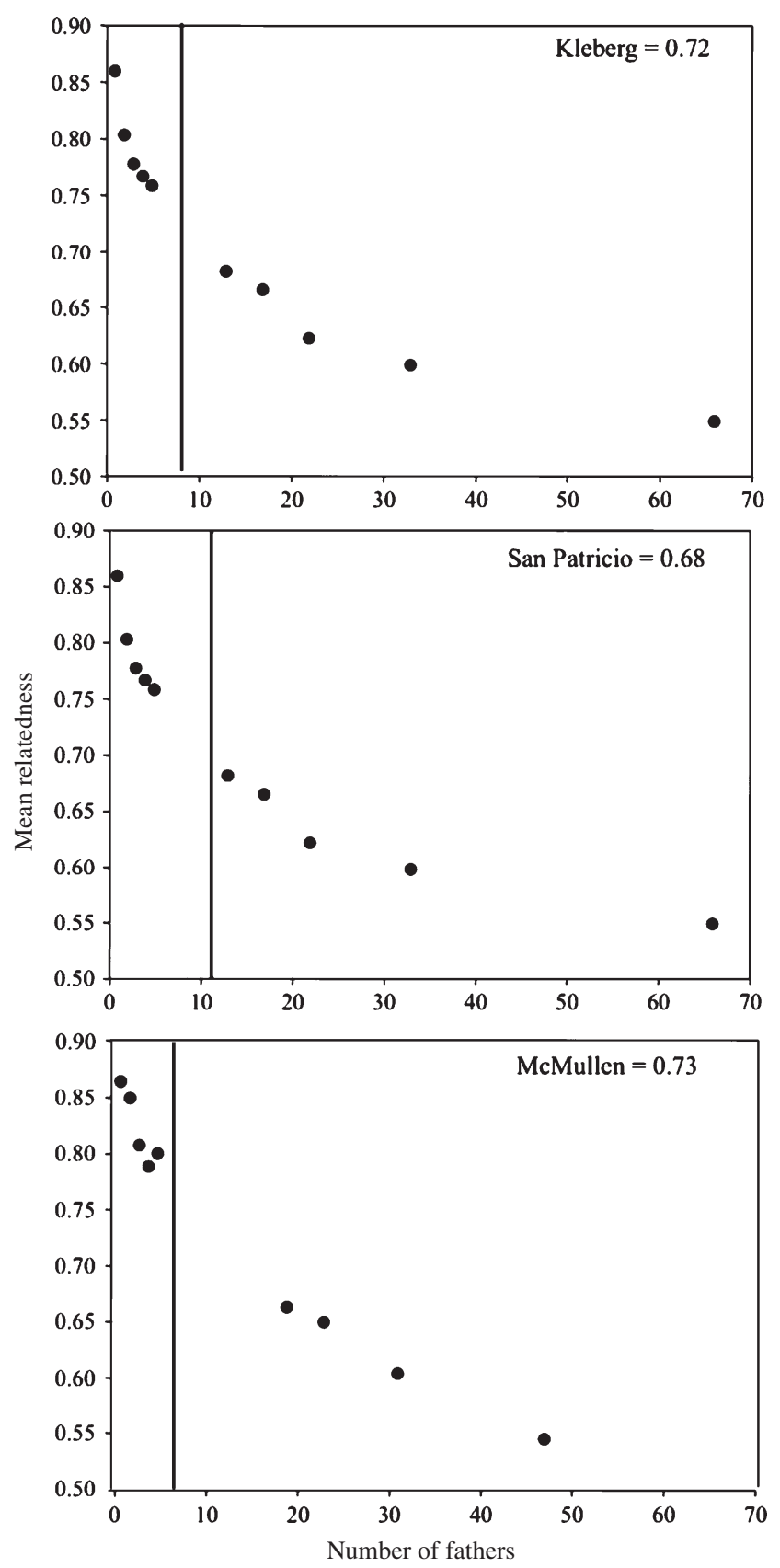

Fig. 3. Mean relatedness (upper right of each panel) of paternal alleles and best-fit value for the average number of offspring sired per male for litters of feral pigs collected in Kleberg, San Patricio, and McMullen Counties and Texas during 2005-07. The vertical line is the intersection of the empirical estimate, with the relatedness curve derived from simulations.

Australia; however, these authors cited unpublished data (P. B. S. Spencer and J. O. Hampton, unpubl. data) that reported promiscuous mating in semiarid habitats.

Estimates of oestrous synchrony suggest that some Texas populations were highly asynchronous. Studies of mammalian mating behaviour indicate that oestrous asynchrony can increase the advantages of mate-guarding as a male tactic, which skews male reproductive success to a small number of dominant males (Ims 1989; Say et al. 2001). However, we found evidence of multiple paternity at sites where matings were both asynchronous and synchronous. Our assessments of oestrous synchrony clearly rely on the assumption that our sample was representative of conceptions in the local area. We sampled 8-18 litters at each site and have no reason to suppose that the samples represent a biased view of oestrous synchrony. If our assessment of oestrous synchrony is correct, promiscuous mating is common under a range of conditions and may not solely be driven by the ability of males to monopolise females.

The factors conducive to multiple mating in Texas feral pigs are not clear. Multiple mating may result from male-male competition, harassment avoidance, or potential genetic benefits for the offspring (Carranza and Valencia 1999; Jennions and Petrie 2000; Chapman 2006). It is also possible that behaviour differs among populations of feral pigs as a response to local forage or demographic conditions. South Texas is an arid environment, with seasonal peaks in availability of foods and water, conditions that may be conducive to increased rates of movement, home-range size and reproduction (e.g. Hampton et al. 2004a). We were not able to directly address the effects of habitat or weather on physical condition and reproduction. Differences in synchrony or timing of oestrous among sites may reflect local differences in rainfall. Nevertheless, we are addressing putative behavioural responses to synchrony of oestrous and not the causal factors of synchrony.

Hunting mortality apparently influenced multiple mating in a European boar population through high turnover of adults (Poteaux et al. 2009). It is difficult to make conclusive statements about the effects of hunting in southern Texas. This is because movements and home range, and thus the neighbourhood size of the local population, are often greater than the hunted or managed areas (Delgado-Acevedo 2010). Therefore, even intense local hunting pressure may not affect all individuals. Finally, feral pigs may simply exhibit different behaviours than wild boar. For instance, invasive species may evolve rapidly in new environments, displaying changes in size, shape, and (in the case of plants) phenology (Johnston and Selander 1964; Harlan 1965; De Wet and Harlan 1975; Easteal 1985). Texas feral pigs have a high proportion of domestic-pig ancestry (R. W. DeYoung, unpubl. data), and it is possible that the domestication process resulted in a selection for behaviours not observed in wild boar.

In addition to feral pigs, multiple paternity has been documented in at least three other species of ungulates, whitetailed deer (Odocoileus virginianus) (DeYoung et al. 2002; Sorin 2004), pronghorn antelope (Antilocapra americana) (Carling et al. 2003) and Soay sheep (Ovis aries) (Pemberton et al. 1999). Each species exhibits differing mating systems, mating strategies, and adaptation to male-male competition (e.g. sperm competition; Reynolds 1996), yet similar rates of multiple mating have been reported. For example, Soay sheep are promiscuous and their anatomy suggests adaptations to sperm competition, whereas pronghorn and white-tailed deer are regarded as dominance-based breeders. Until mating behaviour in additional species and populations of ungulates is characterised, it will be difficult to pinpoint why different 
behaviours, demographic factors and life-history strategies result in similar patterns of mating.

Irrespective of the causal factors, our detection of high rates of multiple mating has important implications for models of disease transmission, where failure to consider animal behaviour may result in inaccurate conclusions. Predictions of disease transmission for non-vector-borne diseases are most reliable when informed by detailed data on contact rates among individuals and populations (Alitzer et al. 2003). However, estimates of contact rates among individuals remain problematic because contact between animals is difficult to observe in the wild (Dexter 2003). This is particularly true for rates of cryptic or infrequent contact, such as sexual contact, among individuals in wild populations. For example, the validity of modelling efforts aimed at predicting the spread of chronic wasting disease in cervids has been criticised because transmission modes and rates of contact among individuals are poorly known (Schauber and Woolf 2003). Similarly, control of bovine tuberculosis in Britain has been difficult because of unexpected changes in the social behaviour of the badger (Meles meles) in response to culling (Macdonald et al. 2008). Feral pigs are capable of breeding year around (Taylor et al. 1998) and may produce two litters every 18 months. Therefore, contact rates among solitary males and female groups (Ilse and Hellgren 1995; Gabor et al. 1999) are much greater than if one assumes a single sire per litter. A high incidence of sexual contact among individuals may increase the opportunity for diseases transmitted by oral or venereal routes, such as swine brucellosis (Godfroid 2002), and pseudorabies (Romero et al. 2001), with implications for human and livestock health.

A high occurrence of multiple mating also has important implications for the development of new management strategies, such as fertility control. Fertility-control strategies in feral pigs include immunocastration (Meloen et al. 1994; Fagerstone et al. 2006; Miller et al. 2006) and development of baits for delivery of pharmaceuticals (Campbell et al. 2006; Campbell and Long 2007). Our data suggest that fertilitycontrol methods targeting males only are likely to be inefficient if female promiscuity is high; methods targeting females or both sexes jointly may be more effective.

\section{Acknowledgements}

We are grateful to M. Reidy, E. Wehland, L. Grassman, G. Timmons, D. Sanders, C. Kubala and Texas Wildlife Services for assistance with sample collection. We thank the many private and public land stewards who granted access to their properties, including the Texas Parks and Wildlife Department, Lower Rio Grande National Wildlife Refuge, Aransas National Wildlife Refuge, Fort Hood Military Installation, King Ranch Inc., the Rob and Bessie Welder Wildlife Foundation, Texas Agrilife and the La Copita Research and Demonstration Area, Shining Ranch, Comanche Ranch, Kubala Family Ranch, and El Pintor Ranch. The Institutional Animal Care and Use Committee at Texas A\&M UniversityKingsville approved all procedures and we followed the guidelines of the American Society of Mammalogists (Gannon and Sikes 2007). This research was supported by a Texas A\&M University-Kingsville University Research Council grant, the USDA Cooperative State Research, Education and Extension Service (CSREES) Biology of Weedy and Invasive Species Program (Project TEXR-2006-03606), and the USDA APHIS Wildlife
Services National Wildlife Research Center. This is publication number 09-106 of the Caesar Kleberg Wildlife Research Institute.

\section{References}

Adams, C. E., Higginbotham, B. J., Rollins, D., Taylor, R. B., Skiles, R., Mapston, M. E., and Turman, S. (2005). Regional perspectives and opportunities for feral hog management in Texas. Wildlife Society Bulletin 33, 1312-1320. doi:10.2193/0091-7648(2005)33[1312:RPA $\mathrm{OFF}] 2.0 . \mathrm{CO} ; 2$

Altizer, S., Nunn, C. L., Thrall, P. H., Gittleman, J. L., Antonovics, J., Cunningham, A. A., Dobson, A. P., Ezenwa, V., Jones, K. E., Pedersen, A. B., Poss, M., and Pulliam, J. R. C. (2003). Social organization and parasite risk in mammals: integrating theory and empirical studies. Annual Review of Ecology, Evolution, and Systematics 34, 517-547.

Barrett, R. H. (1978). The feral hog at Dye Creek Ranch, California. Hilgardia 46, 283-355.

Bieber, C., and Ruf, T. (2005). Population dynamics in wild boar Sus scrofa: ecology, elasticity of growth rate, and implications for the management of pulsed resource consumers. Journal of Applied Ecology 42, 1203-1213. doi:10.1111/j.1365-2664.2005.01094.x

Campbell, T. A., and Long, D. B. (2007). Species-specific visitation and removal of baits for delivery of pharmaceuticals to feral swine. Journal of Wildlife Diseases 43, 485-491.

Campbell, T. A., Lapidge, S. J., and Long, D. B. (2006). Using baits to deliver pharmaceuticals to feral swine in southern Texas. Wildlife Society Bulletin 34, 1184-1189. doi:10.2193/0091-7648(2006)34[1184:UBTD PT]2.0.CO;2

Carling, M. D., Avsharian Wiseman, P., and Byers, J. A. (2003). Microsatellite analysis reveals multiple paternity in a population of wild pronghorn antelopes (Antilocapra americana). Journal of Mammalogy 84, 1237-1243. doi:10.1644/BRB-116

Carranza, J., and Valencia, J. (1999). Red deer females collect on male clumps at mating areas. Behavioral Ecology 10, 525-532. doi:10.1093/beheco/ 10.5.525

Chapman, T. (2006). Evolutionary conflicts of interest between males and females. Current Biology 16, 744-754. doi:10.1016/j.cub.2006. 08.020

De Woody, J. A. (2005). Molecular approaches to the study of parentage, relatedness, and fitness: practical applications for wild animals. The Journal of Wildlife Management 69, 1400-1418. doi:10.2193/0022541X(2005)69[1400:MATTSO]2.0.CO;2

Delgado, R., Fernández-Llario, P., Azevedo, M., Beja-Pereira, A., and Santos, P. (2008). Paternity assessment in free-ranging wild boar (Sus scrofa) Are littermates full-sibs? Mammalian Biology 73, 169-176. doi:10.1016/ j.mambio.2007.07.008

Delgado-Acevedo, J. H. (2010). Feral pig management in southern Texas: a landscape genetics approach. Dissertation, Texas A\&M UniversityKingsville, TX.

De Wet, J. M., and Harlan, J. R. (1975). Weeds and domesticates: evolution in the man-made habitat. Economical Botany 29, 99-107.

Dexter, N. (2003). Stochastic models of foot and mouth disease in feral pigs in the Australian semi-arid rangelands. Journal of Applied Ecology 40, 293-306

DeYoung, R. W., Demarais, S., Gonzalez, R. A., Honeycutt, R. L., and Gee, K. L. (2002). Multiple paternity in white-tailed deer (Odocoileus virginianus) revealed by DNA microsatellites. Journal of Mammalogy 83, 884-892. doi:10.1644/1545-1542(2002)083<0884:MPIWTD $>2.0$. $\mathrm{CO} ; 2$

Dickson, J. G., Mayer, J. J., and Dickson, J. D. (2001). Wild hogs. In 'Wildlife of Southern Forests: Habitat and Management'. (Ed. J. G. Dickson.) pp. 191-208. (Hancock House Publishers: Washington, DC.) 
Easteal, S. (1985). The ecological genetics of the introduced population of the giant toad, Bufo marinus. III. Geographical patterns of variation. Evolution 39, 1065-1075.

Fagerstone, K. A., Miller, L. A., Bynum, K. S., Eisemann, J. D., and Yoder, C. (2006). When, where and for what wildlife species will contraception be a useful management approach? In 'Proceedings of the 22nd Vertebrate Pest Conference'. (Eds R. A. Timm and J. M. O'Brien.) pp. 45-54. (University of California: Berkeley, CA.)

Fleischer, R. C. (1996). Application of molecular methods to the assessment of genetic mating systems in vertebrates. In 'Molecular Zoology: Advances, Strategies, and Protocols'. (Ed. J. D. Ferraris and S. R. Palumbi.) pp. 133-161. (Wiley-Liss: New York.)

Gabor, T. M., Hellgren, E. C., Van Den Bussche, R. A., and Silvy, N. J. (1999). Demography, socio-spatial behavior and genetics of feral pigs (Sus scrofa) in a semi-arid environment. Journal of Zoology 247, 311-322. doi:10.1111/j.1469-7998.1999.tb00994.x

Gannon, W. L., and Sikes, R. S. (2007). Guidelines of the American Society of Mammalogists for the use of wild animals in research. Journal of Mammalogy 88, 809-823. doi:10.1644/06-MAMM-F-185R1.1

Gipson, P. S., Hlavachick, B., and Berger, T. (1998). Range expansion by wild hogs across the central United States. Wildlife Society Bulletin 26, 279-286.

Godfroid, J. (2002). Brucellosis in wildlife. Revue Scientifique et Technique 21, 277-286.

Hampton, J. O., Pluske, J., and Spencer, P. B. S. (2004a). A preliminary genetic study of the social biology of feral pigs in south-western Australia and the implications for management. Wildlife Research 31, 375-381. doi:10.1071/WR03099

Hampton, J. O., Spencer, P. B. S., Alpers, D. L., Twigg, L. E., Woolnough, A. P., Doust, J., Higgs, T., and Pluske, J. (2004b). Molecular techniques, wildlife management and the importance of genetic population structure and dispersal: a case study with feral pigs. Journal of Applied Ecology 41, 735-743. doi:10.1111/j.0021-8901.2004.00936.x

Harlan, J. R. (1965). The possible role of weeds races in the evolution of cultivated plants. Euphytica 14, 173-176.

Hoffman, J. I., Boyd, I. L., and Amos, W. (2003). Male reproductive strategy and the importance of maternal status in the Antarctic fur seal, Arctocephalus gazella. Evolution 57, 1917-1930.

Ilse, L., and Hellgren, E. C. (1995). Spatial use and group dynamics of sympatric collared peccaries and feral hogs in southern Texas. Journal of Mammalogy 76, 993-1002. doi:10.2307/1382593

Ims, R. A. (1989). The potential for sexual selection in males: effect of sex ratio and spatio-temporal distribution of receptive females. Evolutionary Ecology 3, 338-352.

Jennions, M. D., and Petrie, M. (2000). Why do females mate multiply? A review of the genetic benefits. Biological Reviews of the Cambridge Philosophical Society 75, 21-64. doi:10.1017/ S0006323199005423

Johnston, R. F., and Selander, R. K. (1964). House sparrows: rapid evolution of races in North America. Science 144, 548-550.

Jones, A. G., and Ardren, W. R. (2003). Methods of parentage analysis in natural populations. Molecular Ecology 12, 2511-2523. doi:10.1046/ j.1365-294X.2003.01928.x

Kammermeyer, K., Bowers, J., Cooper, B., Forster, D., Grahl, K., Holbrook, T., Martin, C., McDonald, S., Nicholson, N., Van Brackle, M., and Waters, G. (2003). Feral hogs in Georgia: disease, damage, and control. Georgia Department of Natural Resources, Atlanta.

Kenagy, G. J., and Trombulak, S. C. (1986). Size and function of mammalian testes to body size. Journal of Mammalogy 67, 1-22. doi:10.2307/138 0997

MacDonald, D. W., Newman, N., Buesching, C. D., and Johnson, P. J. (2008). Male-biased movement in a high density population of the Eurasian badger (Meles meles). Journal of Mammalogy 89, 1077-1086. doi:10.1644/07-MAMM-A-185.1
Mapston, M. E. (2004). Feral hogs in Texas. Texas Cooperative Extension Service, College Station, TX.

Marshall, T. C., Slate, J., Kruuk, L. E. B., and Pemberton, J. M. (1998). Statistical confidence for likelihood-base paternity inference in natural populations. Molecular Ecology 7, 639-655. doi:10.1046/j.1365-294x. 1998.00374.x

Mayer, J. J., and Brisbin, I. L. (Eds) (1991). 'Wild Pigs in the United States: Their History, Comparative Morphology, and Current Status.' (University of Georgia Press: Athens.)

Meloen, R. H., Turkstra, J. A., Lankhof, H., Puijk, W. C., Schaaper, W. M. M., Dijkstra, G., Wensing, C. J. G., and Oonk, R. B. (1994). Efficient immunocastration of male piglets by immunoneutralization of $\mathrm{GnRH}$ using a new GnRH-like peptide. Vaccine 12, 741-746. doi:10.1016/ 0264-410X(94)90226-7

Miller, J. E. (1993). A national perspective on feral swine. In 'Feral Swine: A Compedium for Resource Managers'. (Eds C. W. Hanselka and J. F. Cadenhead.) pp. 9-16. (Texas Cooperative Extension Service: Uvalde, TX.)

Miller, L. A., Talwar, P. G., and Killian, J. K. (2006). Contraceptive effect of a recombinant $\mathrm{GnRH}$ vaccine in adult female pigs. In 'Proceedings of the 22nd Vertebrate Pest Conference'. (Eds R. A. Timm and J. M. O'Brien.) pp. 106-109. (University of California: Berkeley, CA.)

Nettles, V. F. (1997). Feral swine: where we've been, where we're going. In 'Proceedings of the National Feral Swine Symposium'. (Ed. K. L. Schmitz.) pp. 1-9. (United States Department of Agriculture, Animal and Plant Health Inspection Service: Riverdale, MD.)

Odlaug, T. O. (1965). 'Laboratory Anatomy of the Feral Pig.' 3rd edn. (William C. Brown Co.: Dubuque, IA.)

Pemberton, J. M., Coltman, D. W., Smith, J. A., and Pilkington, J. G. (1999). Molecular analysis of a promiscuous, fluctuating mating system. Biological Journal of the Linnean Society. Linnean Society of London 68, 289-301. doi:10.1111/j.1095-8312.1999.tb01170.x

Pimentel, D., Zuniga, R., and Morrison, D. (2005). Update on the environmental and economic costs associated with alien-invasive species in the United States. Ecological Economics 52, 273-288.

Poteaux, C., Baubet, E., Kaminski, G., Brandt, S., Dobson, F. S., and Baudoin, C. (2009). Socio-genetic structure and mating system of a wild boar population. Journal of Zoology 278, 116-125. doi:10.1111/j.1469-7998. 2009.00553.x

Queller, D. C., and Goodnight, K. F. (1989). Estimation of genetic relatedness using allozyme data. Evolution 43, 258-275. doi:10.2307/2409206

Reynolds, J. D. (1996). Animal breeding systems. Trends in Ecology \& Evolution 11, 68-72. doi:10.1016/0169-5347(96)81045-7

Romero, C. H., Meade, J. E., Shultz, J. E., Chung, H. Y., Gibbs, E. P. J., Hahn, E. C., and Lollis, G. (2001). Venereal transmission of pseudorabies viruses indigenous to feral swine. Journal of Wildlife Diseases 37, 289-296.

Say, L., Pontier, D., and Natoli, E. (2001). Influence of oestrus synchronization on male reproductive success in the domestic cat (Felis catus L.). Proceedings. Biological Sciences 268, 1049-1053. doi:10.1098/rspb.2001.1583

Schauber, E. M., and Woolf, A. (2003). Chronic wasting disease in deer and elk: a critique of current models and their application. Wildlife Society Bulletin 31, 610-616.

Sneath, P. H. A., and Sokal, R. R. (1973). 'Numerical Taxonomy: The Principles and Practice of Numerical Classification.' (W. H. Freeman and Co.: San Francisco, CA.)

Sorin, A. B. (2004). Paternity assignment for white-tailed deer (Odocoileus virginianus): mating across age classes and multiple paternity. Journal of Mammalogy 85, 356-362. doi:10.1644/1545-1542(2004)085<0356: $\mathrm{PAFWDO}>2.0 . \mathrm{CO} ; 2$

Southeastern Cooperative Wildlife Disease Study (2009). National feral swine mapping system. Available at http://128.192.20.53/nfsms/ [accessed 19 November 2009]. 
Stevens, R. (1996). 'The Feral Hog in Oklahoma.' (Samuel Roberts Noble Foundation: Ardmore, OK.)

Sweeney, J. R., Sweeney, J. M., and Sweeney, S. W. (2003). Feral hog. In 'Wild Mammals of North America'. (Eds G. Feldhamer, B. Thomson and J. Chapman.) pp. 1164-1179. (Johns Hopkins University Press: Baltimore, MD.)

Taylor, R. B. (1993). History and distribution of feral hogs in Texas. In 'Feral Swine: A Compendium for Resource Managers'. (Eds C. W. Hanselka and J. F. Cadenhead.) pp. 17-27. (Texas Cooperative Extension Service: Uvalde, TX.)
Taylor, R. B., Hellgren, E. C., Gabor, T. M., and Ilse, L. (1998). Reproduction of feral pigs in southern Texas. Journal of Mammalogy 79, 1325-1331. doi: $10.2307 / 1383024$

Witmer, G. W., Sanders, R. B., and Taft, A. C. (2003). Feral swine: are they a disease threat to livestock in the United States? In 'Proceedings of the 10th Wildlife Damage Management Conference'. (Eds K. A. Fagerstone and G. Witmer.) pp. 316-325. (The Wildlife Damage Management Working Group of The Wildlife Society: Fort Collins, CO.)

Manuscript received 16 March 2010, accepted 28 August 2010 